\title{
Development of Structural Type Mortars Reinforced with Corn Fiber (Zea Mays).
}

\author{
Mónica Monsalve $^{1 *}$, Oscar Higuera ${ }^{2}$, Pedro Estrada ${ }^{2}$, Marlyn Orozco $^{2}$ and Cristian Pedraza² \\ ${ }^{1}$ Department of Mechanical and Mechatronic Engineering, National University of Colombia. Cr 45 \# 26-85. Bogotá, Colombia. \\ ${ }^{2}$ CONFORMAT Research Group, Mechanical Engineering program, University of Atlántico. Km 7 Antigua via Puerto Colombia, \\ Colombia
}

Received 12 October 2018; Accepted 12 August 2019

\begin{abstract}
In this investigation, structural type mortars reinforced with corn fibers were elaborated; these fibers were previously treated with flaxseed oil and paraffin, cut to lengths of 1,2 and $5 \mathrm{~cm}$, and weighed, in order to obtain a ratio of $0.5 \%$ and $1 \%$ by weight with respect to the quantity of cement. The fibers were physic chemically characterized by Thermogravimetric Analysis (TGA), Derivative Thermogravimetry (DTG) and Fourier Transform Infrared Spectrometry (FTIR), and their chemical resistance was evaluated by exposing them to a concentrated solution of $\mathrm{Ca}(\mathrm{OH}) 2$ that simulated the alkaline medium of the cement. The fiber-reinforced mortars were mechanically characterized by compression and bending tests, which were performed 7, 21 and 28 days after processing. The results show that after 28 days the paraffin-coated corn fiber reinforced mortars, with $1 \mathrm{~cm}$ in length and $0.5 \%$ in weight presented the best results, an increase in the compressive and flexural strength of $16.92 \%$ and $38.51 \%$ respectively was noted, compared to the unreinforced mortar.
\end{abstract}

Keywords: Reinforcement mortar, corn fiber, compressive strength, flexural strength.

\section{Introduction}

The use of natural fibers as reinforcement material in the construction industry is quite economical and accessible since they only require a low degree of industrialization to be processed and, in comparison with synthetic fibers, the energy used for their production is small. Therefore the manufacturing cost is low $[1,2]$. Although historically many fibers have been used to reinforce various building materials, it has been until recent years that scientists have been studying natural fibers as reinforcement, since previously their use was limited exclusively to the production of clothing, mattresses, and blankets [3].

The purpose of reinforcement fibers is to improve the mechanical properties of building material, due to their properties, vegetable threads improve the flexibility and breaking strength of the resulting material, among other benefits [4]. However, industrial production of plant-based fiber-reinforced cement mortars is currently very limited due to lack of durability durabilidad [5]. For this reason, over the last decade, strength has been made to improve the quality of these composite materials. The main cause of the loss of resistance is due to the presence of calcium hydroxide $\mathrm{Ca}(\mathrm{OH})_{2}$, since, in an alkaline environment, the calcium ion reacts with the cellulose and breaks the long polymer chains. Another problem that exists is the volumetric changes of the fibers in the matrix, in addition to their predisposition to the attack of microorganisms in damp environments húmedos [6, 7].

To counteract degradation and improve the durability of plant-based fiber reinforced cement mortars, the composition

\footnotetext{
*E-mail address: momonsalvea@unal.edu.co

ISSN: $1791-2377 @ 2019$ School of Science, IHU. All rights reserved.

doi:10.25103/jestr.124.08
}

of the matrix must first be modified to reduce the alkaline compounds that cause the cellulose to lose its ability to reinforce. To this end, it is necessary to analyses the dosage of raw materials by means of the development of a mix design, which allows for a performance similar to that of mortars prepared solely with Portland cement. The second option consists of modifying the surface of the fibers using hydrophobic substances that allow them to be coated, protecting them from the alkaline environment to which they would be exposed and reducing the amount of water that the fiber can absorb, which will provide stability in the cement matrix [8].

The chemical composition of the corn plant is similar to that of other widely studied and used as reinforcements in cement-based matrices. It is basically made up of cellulose, hemicellulose, and lignin [9]. Prado Martínez et al [10] reported that corn husk has a chemical composition of $78.86 \%$ Holocellulose, $43.14 \alpha$-Cellulose, $23.00 \%$ Lignin and $0.761 \%$ Ash. On the other hand, Gonzalez et al [11] found that corn Tusa leaf has a chemical composition of cellulose between $18-40 \%$ hemicellulose between $31-34 \%$ and lignin between 14 and $19 \%$.

Petroudy (2017) [12] reported that the corn stem fibers have a micro fibers angle of $10.9^{\circ}$ and that cellulose has a crystallinity between 52 and $59 \%$. The micro threads angle refers to the angle that microfibers make with respect to the axis of the fiber, this parameter is important, as it affects the inherent strength properties of the fiber. The higher the microfibers angle, the greater the deformation at the break, as the fibers may twist when stretched. A small angle determines the general anisotropic properties of the fiber.

In this paper, structural type mortars reinforced with corn fiber were elaborated in order to determine the influence of the protective substance, the length, and percentage by weight 
of the fiber on the mechanical properties of the reinforced mortar.

\section{Experimental Methodology}

\subsection{Mortar Dosage}

For the correct dosage of the mortar, a mix design was carried out following the methodology proposed by Sánchez de Guzmán [13], which allowed the respective proportions of cement, water, and fine aggregate to be determined. For this, Argos Portland type I cement was used, with a specific weight of $3.12 \mathrm{~g} / \mathrm{cm}^{3}$ and $98 \%$ fineness. The sand used to make the mortars was quarry sand from Santo Tomás Atlántico, which was clean, cube-shaped, rough textured sand with a fineness modulus of 2.25 , a dry apparent density of $2.54 \mathrm{~g} / \mathrm{cm}^{3}$, a nominal density of $2.62 \mathrm{~g} / \mathrm{cm}^{3}$, a water absorption percentage of 1.21 and a granulometry of $0.088 \mathrm{~cm}(\mathrm{~d} 80)$. A mortar with a plastic consistency of $110 \%$ was obtained. Table 1 shows the quantities used for each of the components of the mixture. The amount of fiber was calculated in relation to the amount of cement.

Table 1. Mixture used in this study

\begin{tabular}{c|c}
\hline Materials & Quantity (kg) \\
\hline Cement & 14.81 \\
Water & 10.96 \\
Sand & 56.88 \\
Corn Fiber $(0.5 \%)$ & 0.074 \\
Corn Fiber (1\%) & 0.1481 \\
Ratio Water-Cement (A/C) & 0.74 \\
\hline
\end{tabular}

Table 2. Design of experiments

\begin{tabular}{|c|c|c|c|c|}
\hline $\begin{array}{l}\text { Type of } \\
\text { fiber }\end{array}$ & $\begin{array}{l}\text { Protectiv } \\
\text { e } \\
\text { substanc } \\
\text { e }\end{array}$ & $\begin{array}{c}\text { Lengt } \\
\text { h } \\
(\mathrm{cm})\end{array}$ & $\begin{array}{c}\text { Percentag } \\
\text { e by } \\
\text { weight }\end{array}$ & $\begin{array}{c}\text { Numbe } \\
\text { r of test } \\
\text { pieces }\end{array}$ \\
\hline \multirow{6}{*}{$\begin{array}{l}\text { Corn } \\
\text { fiber }\end{array}$} & \multirow{3}{*}{$\begin{array}{c}\text { Flaxseed } \\
\text { oil }\end{array}$} & 1 & $\begin{array}{c}0.5 \\
1 \\
\end{array}$ & $\begin{array}{l}12 \\
12 \\
\end{array}$ \\
\hline & & 2 & $\begin{array}{c}0.5 \\
1 \\
\end{array}$ & $\begin{array}{l}12 \\
12 \\
\end{array}$ \\
\hline & & 5 & $\begin{array}{c}0.5 \\
1 \\
\end{array}$ & $\begin{array}{l}12 \\
12 \\
\end{array}$ \\
\hline & \multirow{3}{*}{ Paraffin } & 1 & $\begin{array}{c}0.5 \\
1\end{array}$ & $\begin{array}{l}12 \\
12\end{array}$ \\
\hline & & 2 & $\begin{array}{c}0.5 \\
1\end{array}$ & $\begin{array}{l}12 \\
12\end{array}$ \\
\hline & & 5 & $\begin{array}{c}0.5 \\
1\end{array}$ & $\begin{array}{l}12 \\
12\end{array}$ \\
\hline $\begin{array}{l}\text { Referenc } \\
\text { e sample }\end{array}$ & & & & 6 \\
\hline Total & \multicolumn{4}{|c|}{150} \\
\hline
\end{tabular}

Table 2 summarizes the design of experiments used in this research, whose response variable is the resistance to compression and flexion, taking as possible factors that would influence the mechanical properties: protective substance, fiber length and percentage by weight.

\subsection{Preparation And Conditioning Of Fibers}

The procedure for the preparation and conditioning of the fibers is detailed in Figure 1. Paraffin and flaxseed oil were chosen as protective substances because they are economical and do not damage the mortar.

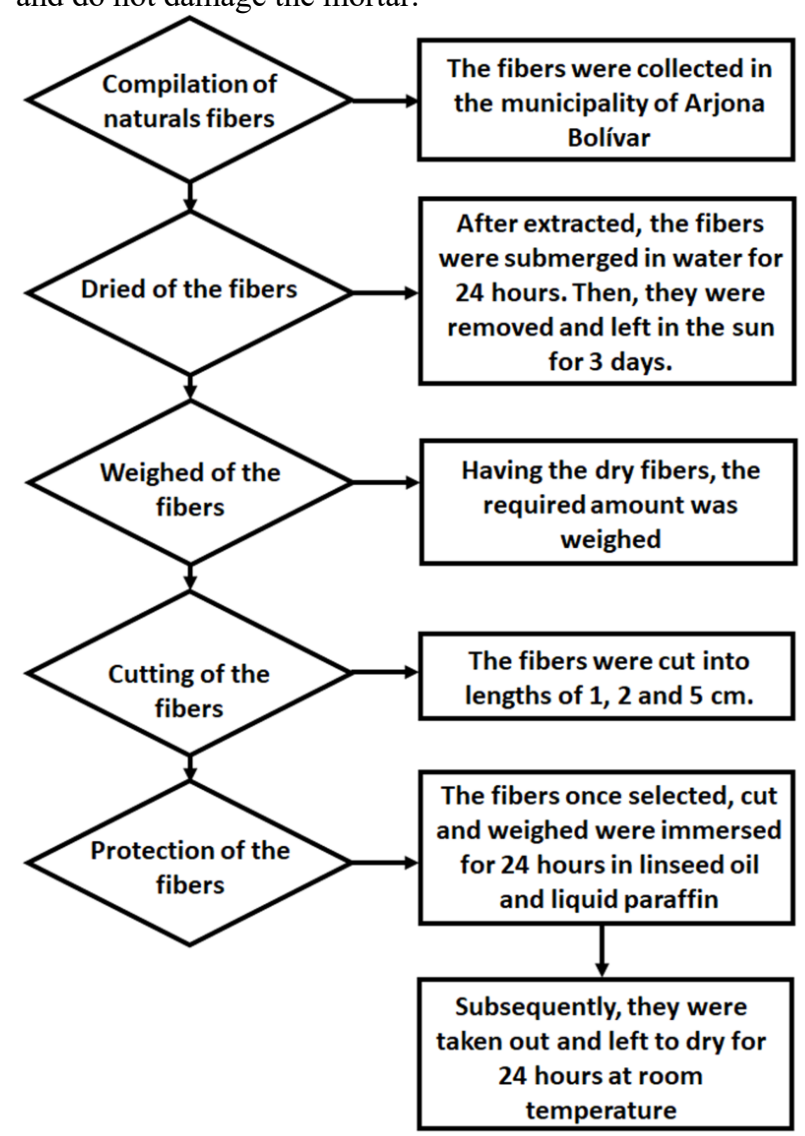

Fig. 1. Procedure for the preparation of the fibers

\subsection{Physical-Chemical Characterization of the Fibres}

The chemical resistance to alkaline environments was measured from the weight loss of the fibers after they were immersed in a solution of $\mathrm{Ca}(\mathrm{OH})_{2} 1 \mathrm{~N}$ at $20^{\circ} \mathrm{C}$ for 7,21 and 28 days. The test consisted of introducing a known quantity $(\mathrm{W} 1=0.200 \mathrm{~g}$ ) of each fiber sample into $100 \mathrm{ml}$ of solution. At the end of the established test period, the fibers were removed and dried at a temperature of $105^{\circ} \mathrm{C}$ to a constant weight $\left(\mathrm{W}_{2}\right)$. The percentage of chemical resistance (Pcr) was calculated according to equation 1 [14]:

$$
P_{c r}=100 x \frac{w_{1}-w_{2}}{w_{1}}
$$

The fibers treated with flaxseed oil and paraffin were observed in a LEICA MC 120 HD 25 X/9.5 Stereoscope with a standard magnification of $160 \mathrm{X}$ and resolution of $1050 \mathrm{lp} /$ $\mathrm{mm},(0.95 \mu \mathrm{m})$. The infrared spectra of the corn fibers were obtained in the range of $400-4000 \mathrm{~cm}-1$, the infrared spectra of the corn fibers were obtained in the range of $400-4000$ $\mathrm{cm}^{-1}$, resolution $2 \mathrm{~cm}-1$, for sample preparation was used $\mathrm{KBr}$ tablet with sample concentration and number of scans 45 , was utilized a Shimadzu IRAffinity-1 FTIR equipment and the thermal degradation of the fibers was studied by Thermogravimetric Analysis (TGA). A Thermogravimetric Analyzer model HI-Res Modulated TGA 2950 was used for this purpose. In order to prevent thermo-oxidative reactions, the analysis was carried out in an inert nitrogen atmosphere with a $50 \mathrm{ml} / \mathrm{min}$ nitrogen atmosphere and a constant heating rate of $10^{\circ} \mathrm{C} / \mathrm{min}$, in a temperature range between $25^{\circ} \mathrm{C}$ and $750^{\circ} \mathrm{C}$. 


\subsection{Mechanical Characterization}

To evaluate the strength of the fibers reinforced mortars, compression, and bending tests were carried out using a Yueke universal testing machine with a speed of $10 \mathrm{~mm} / \mathrm{min}$. The test of resistance to compression was carried out under the guidelines of the NTC 673 standard [15], for this purpose, reusable PVC molds [16] with cylindrical geometry and dimensions of $5.08 \mathrm{~cm} \mathrm{x} 10.16 \mathrm{~cm}$ [17] were developed. The bending strength test was carried out in accordance with the INV.E-324-07 standard [18], for which rectangular geometry specimens (beams) with dimensions of $4 \times 4 \times 16 \mathrm{~cm}$ were developed (Figure 2). Specimens were manufactured in duplicate and tested at 7,21 and 28 days.

\section{Analysis and Discussion of Results}

\subsection{Physical-Chemical Characterization of the Fibers}

\subsubsection{Chemical resistance.}

It is important to note that in order for a material to be used as a reinforcement in cement it must be able to withstand a chemical attack without suffering a considerable loss in strength [2]. Natural fibers are particularly vulnerable to alkalinity due to the chemical decomposition of lignin and cellulose by $\mathrm{Ca}(\mathrm{OH})_{2}$ and are the main cause of deterioration by the brittleness of the fiber in concrete. The alkalinity of the water in the pore of the matrix dissolves the lignin by breaking the bond of the individual microcells which absorb calcium hydroxide calcio [19]. Reactions that occur during cement hydration release lime, which is separated as $\mathrm{Ca}\left(\mathrm{OH}_{2}\right.$ and produces a highly alkaline solution $(\mathrm{pH} \sim 12)$ that can attack any reinforcing material. Equation 3 and 4.

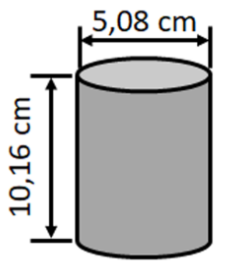

(a)

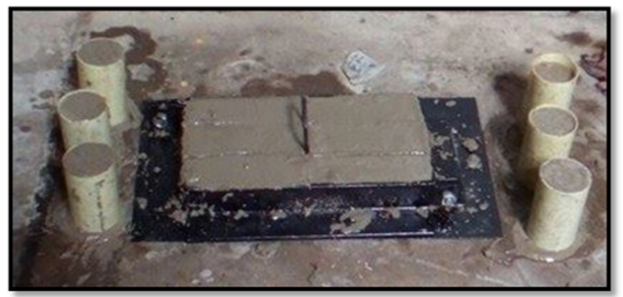

(c)

Fig. 2. Test specimen a) compression test, b) bending test and c) molten specimens

$$
\begin{array}{ll}
2 C_{3} S+7 \mathrm{H} \rightarrow \mathrm{C}_{3} S_{2} H_{4}+3 \mathrm{CH} & \Delta \mathrm{H}=-1114 \mathrm{KJ} / \mathrm{mol} \\
2 C_{2} S+5 H \rightarrow \mathrm{C}_{3} S_{2} H_{4}+C H & \Delta \mathrm{H}=-43 \mathrm{KJ} / \mathrm{mol}
\end{array}
$$

Where: $\mathrm{CH}=\mathrm{Ca}(\mathrm{OH})_{2} ; \mathrm{C}_{3} \mathrm{~S}=$ Tricalcium Silicate; $\mathrm{C}_{2} \mathrm{~S}=$ Dicalcium Silicate and $\mathrm{H}=\mathrm{H}_{2} \mathrm{O}$

Johnston et al (2010) [20] propose that the chemical attack of fibers can occur in various forms, 1) the molecular chains of cellulose are oxidized and broken by alkalis, particularly at warm temperatures. 2) Hemicellulose is similar, but due to its low degree of polymerization, it is more affected. 3) Lignin, which binds to cellulose-based fibers, tends to dissolve in alkalis, particularly at warm temperatures. In conclusion, the rate of deterioration depends on the proportions of cellulose, hemicellulose, and lignin present in the natural fiber. Of the three, cellulose is the most resistant to alkalis, which is why treatments are used to reduce the content of hemicellulose and lignin as reinforcement in cement, in order to reduce the deterioration related to alkalis. A lower degree of swelling or weight gain is considered indicative of increased chemical resistance [21].

Juarez et al (2002) stated that the decomposition of cellulose and hemicellulose in an alkaline medium could be presented by two different mechanisms, defibrillation, and alkaline hydrolysis. Defibrillation occurs when cellulose made up of linear glucose chains dissolves when it reacts with the $\mathrm{OH}$ ion producing $-\mathrm{CH}_{2} \mathrm{OH}$ which is released from the molecular chain. Defibrillation is thus continuous during exposure to alkaline media and occurs at room temperature below $75{ }^{\circ} \mathrm{C}$. Alkaline hydrolysis causes the division of molecular chains and combines with the above mechanism, as the division of the molecular chain causes the exposure of reductive end units. This mechanism is generally carried out at temperatures around $100^{\circ} \mathrm{C}[22]$.

Almeida Melo et al (2013) [23] proposed 2 mechanisms for the degradation of sisal fibers. The main mechanism is the deposition of calcium hydroxide crystals on the fiber surface, which leads to the fiber mineralization process, which in turn may reduce the amount of cellulose. A secondary and less severe mechanism is the degradation of lignin and hemicellulose through the absorption of calcium and hydroxide ions. The possible chemical reaction between the alkaline solution and the $\mathrm{OH}$ of the fiber is [24]

$$
\text { Fiber- } \mathrm{OH}+\mathrm{Ca}(\mathrm{OH})_{2} \rightarrow \text { Fiber- } \mathrm{O}^{-} \mathrm{Ca}^{++}+\mathrm{H}_{2} \mathrm{O}
$$

Wei et al (2015) [25] argued that the alkaline degradation of natural fiber in a cement matrix is due to the high alkalinity of the solid phase of the cement and the pore solution. The above can be presented in 4 steps, 1) Degradation of lignin and part of the hemicellulose, which leads to exposure of the holocellulose in the pore solution and solid phase of the matrix; 2) Degradation occurs mainly in the hemicellulose, which causes decreased integrity and stability of the cell wall of the natural fiber; 3) After the degradation of lignin, hemicellulose, and intramolecular hydrogen bonds, there are no bonds left in the microfibers of hemicellulose, and as a result the cellulose fibers are dispersed in the pore solution of the matrix which in turn accelerates the degradation of the cellulose; 4) The last step is the failure of the cellulose microfibers, which is caused by the alkaline hydrolysis of the amorphous regions that do not contain final reducers and this leads to the complete degradation of the natural fiber. As degradation progresses, hydration products such as hydrated calcium silicate $(\mathrm{C}-\mathrm{S}-\mathrm{H})$ and the soluble phase of $\mathrm{Ca}(\mathrm{OH})_{2}$ (portandlite) gradually infiltrate the cell wall, which in turn leads to mineralization and brittleness of the natural fiber. Except for the alkaline hydrolysis of the 3 main components, cell wall mineralization is also an important mechanism of degradation, which leads to the brittleness of the fiber and the reduction of strength and deformation capacity. During cell wall mineralization 2 main mechanisms may occur; 1) Mineralization - $\mathrm{Ca}(\mathrm{OH})_{2}$ and self-mineralization which are caused by migration of hydration products, $\left(\left(\mathrm{Ca}(\mathrm{OH})_{2}\right.\right.$, to the 
lumens and to the middle lamella) and variations in volume), $\mathrm{Ca}(\mathrm{OH})_{2}$ mineralization, indicate that the $\mathrm{Ca}(\mathrm{OH})_{2}$ content of the matrix and $\mathrm{Ca}^{2+}$ concentration in the pore solution contribute to the natural degradation of the fiber. However, self-mineralization demonstrates the rate of hydrolysis of the amorphous components (lignin and hemicellulose), so the contribution of the alkalinity of the matrix to the degradation of the fiber can be determined. It is well known that the precipitation of hydration products such as $\mathrm{Ca}(\mathrm{OH})_{2}$ within the cell wall structure is the main reason for cell wall mineralization.

Figure 3 shows the behavior of protectively coated corn fiber (paraffin and flaxseed oil) before (Figure $3 \mathrm{a}$ and $3 \mathrm{~b}$ ) and after 28 days of immersion in $\mathrm{Ca}(\mathrm{OH})_{2}$ (Figure $3 \mathrm{c}$ and $3 \mathrm{~d}$ ).

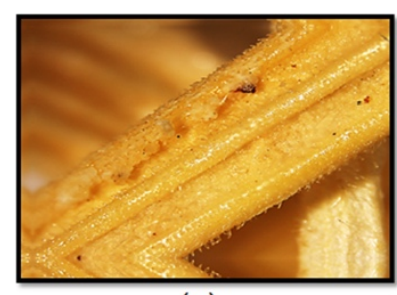

(a)

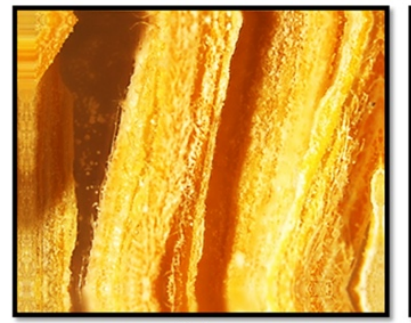

(c)

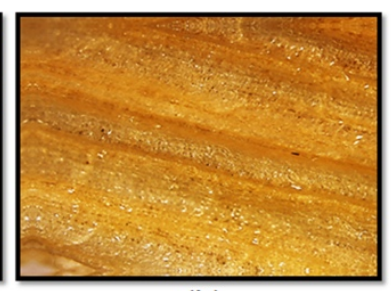

(b)

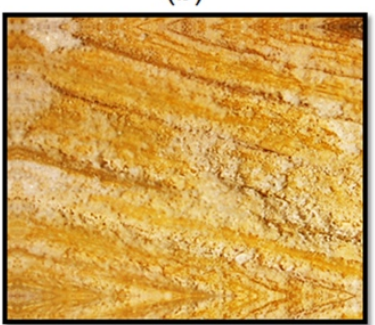

(d)
Fig. 3. a) Corn fiber protected with paraffin, b) Corn fiber protected with flaxseed oil, c) Corn fiber protected with paraffin and d) Corn fiber protected with flaxseed oil, submerged for 28 days in $\mathrm{Ca}(\mathrm{OH})_{2}$.

Figure 3 a shows how the corn fiber is coated with paraffin before being immersed in $\mathrm{Ca}(\mathrm{OH})_{2}$. It can be seen that the paraffin almost completely covers the surface of the fiber, thus guaranteeing better protection against the alkaline environment.

Figure $3 \mathrm{~b}$ shows the corn fiber coated with flaxseed oil before being immersed in $\mathrm{Ca}(\mathrm{OH})_{2}$. It can be seen that flaxseed oil does not completely cover the surface of the fiber and therefore does not guarantee good protection against the alkaline environment. This explains the variation in chemical resistance obtained.

In Figure $3 c$ we can see how the small filaments of the fibers begin to detach from the surface, thus indicating that the fiber is probably degraded by defibrillation, we can also see areas where the fiber was exposed to the alkaline medium of the solution, since it has deposition of $\mathrm{Ca}(\mathrm{OH})_{2}$ crystals on the surface, obtaining a chemical resistance of $85.36 \%$. As for the corn fibers covered with flaxseed oil (Figure 3d), white areas are observed due to the deposition of $\mathrm{Ca}(\mathrm{OH})_{2}$ crystals on the surface and even some holes, this is due to the fact that in these regions the flaxseed oil was not well impregnated, leaving places exposed to the alkaline medium of the solution obtaining a lower chemical resistance (64.18\%). In conclusion, it was determined that the substance that offered the best protection to the fibers after 28 days of immersion in an alkaline medium was paraffin, possibly because it interacts better with the fiber, so its molecular structures are similar, since both are composed of long chains, where the paraffin has hydrocarbon chains, and the fiber has molecular chains like glucose [19].

3.1.2 Fourier Transform Infrared Spectroscopy (FT-IR). Figure 4 shows the infrared spectra for coated and uncoated corn fiber. Figure $4 \mathrm{a}$ shows the characteristic axial vibrations of the groups associated with the cellulose molecule, lignin, and hemicellulose, which are part of the fiber composition. The most pronounced bands in the spectrum are those belonging to the polymeric association of hydroxyl groups and the $\mathrm{OH}$ bond tension of intermolecular hydrogen bridges present in carbohydrates (cellulose + hemicellulose) and lignin $\left(3461.87 \mathrm{~cm}^{-1}\right.$ and $\left.3407.87 \mathrm{~cm}^{-1}\right)$ [26]. In addition, the bands of $\mathrm{O}-\mathrm{H}$ stretching associated with carboxylic acid $\left(2361.75 \mathrm{~cm}^{-1}, 2328.97 \mathrm{~cm}^{-1}\right)$ and the bands belonging to the RNH "R" groups of secondary amines $\left(1650 \mathrm{~cm}^{-1}-1560.36\right.$ $\left.\mathrm{cm}^{-1}\right)$ are observed. The bands of carbonyl $(\mathrm{C}=\mathrm{O})$ stretching associated with ketones $\left(1539.14 \mathrm{~cm}^{-1}\right)$ and the band belonging to carbon dioxide, $\mathrm{CO}_{2}$, is also present $\left(670 \mathrm{~cm}^{-1}\right)$ [27-29].

In Figure $4 \mathrm{~b}$ it can be seen that the infrared spectra show for all the fibers the presence of bands associated with the vibrations of $\mathrm{O}-\mathrm{H}$ belonging to the lignin phenols and to the hydroxyl bands of cellulose and hemicellulose (3400-3420 $\left.\mathrm{cm}^{-1}\right)$ ) [30], at the asymmetric tension $\mathrm{CH}_{2}$ - cellulose $(2850$ $\mathrm{cm}^{-1}$ ) corresponding to $\mathrm{CH}_{2}-\mathrm{CO}-$; the bending of all active methylenes is observed as a series of intense and sharp bands at 1465 to $1380 \mathrm{~cm}^{-1}$ and bands belonging to the nitro $-\mathrm{CNO}_{2}$ stretch group $\left(871.87 \mathrm{~cm}^{-1}\right)$. Similarly, the presence of fluoroalkanes $\left(1000-1100 \mathrm{~cm}^{-1}\right)$ in the sample is attributed to the use of paraffin as an impregnating substance, which, being a substance obtained from the distillation of petroleum, is made up of a series of hydrocarbons and elements such as F, $\mathrm{Cl}, \mathrm{Br}$, among others. In the samples of submerged fibers during 21 days, bands belonging to the stretching of the $\mathrm{O}-\mathrm{H}$ group were found in carboxylic acid $\left(2500.81 \mathrm{~cm}^{-1}\right)$, bands associated with the balance of the $-\left(\mathrm{CH}_{2}\right) \mathrm{n}$ group, present when $\mathrm{n}>=4\left(711.76 \mathrm{~cm}^{-1}\right)$ and bands corresponding to the vibration by torsion of the $\mathrm{C}-\mathrm{OH}$ link $\left(668.89 \mathrm{~cm}^{-1}\right)$. The band representing the symmetrical and asymmetrical bending of the 3 hydrogen's of the R-CH group $=\mathrm{CH}_{2}\left(1654.03 \mathrm{~cm}^{-1}\right)$ was only found in the samples taken at 28 days [27, 28, 31-33]

In Figure $4 \mathrm{c}$ it can be seen that the infrared spectra show, for all the fibers, bands corresponding to the vibrations of $\mathrm{O}$ $\mathrm{H}$ belonging to the phenols of lignin and to the hydroxyl peaks of cellulose and hemicellulose $\left(3400-3420 \mathrm{~cm}^{-1}\right)$ [30], to the vibrations of $\mathrm{COOH}$; stretching of the $\mathrm{O}-\mathrm{H}$ of carboxylic acid (3000-2201 cm $\left.\mathrm{cm}^{-1}\right)$, asymmetric stress $\mathrm{CH}_{2}$ - cellulose $(2850$ $\left.\mathrm{cm}^{-1}\right)$, ring structure vibrations $(\mathrm{C}=\mathrm{C})$ characteristic of lignin $\left(1561 \mathrm{~cm}^{-1}\right)$, bands belonging to $\mathrm{C}-\mathrm{H}$ bond vibrations (1054 $\left.\mathrm{cm}^{-1}, 1033.88 \mathrm{~cm}^{-1}\right)$, the bands belonging to the $\mathrm{CNO}_{2}$ nitro group stretching $\left(870 \mathrm{~cm}^{-1}\right)$ and the band associated with the asymmetric vibrations of $\mathrm{C}-\mathrm{H}_{2}$ and the bands corresponding to the stretching of the O-H of carboxylic acid $\left(2495.03 \mathrm{~cm}^{-1}\right.$, $2352.29 \mathrm{~cm}^{-1}$ ) that are present in the samples taken at 7 and 21 days. In the sample taken after 7 days, bands associated with the vibrations of the $\mathrm{C}=\mathrm{O}$ groups present in the hemicellulose $\left(1735.04 \mathrm{~cm}^{-1}\right)$ were found. A band associated with O-H stretching in a carboxylic acid $\left(2495.03 \mathrm{~cm}^{-1}\right)$ was found in the 21-day sample. After 28 days, bands were found corresponding to the torsional vibration of the $\mathrm{C}-\mathrm{OH}$ link $\left(647 \mathrm{~cm}^{-1}\right)[27,28,31,32]$.

It can also be seen from Figures $4 \mathrm{~b}$ and $4 \mathrm{c}$ that the bands corresponding to the $\mathrm{O}-\mathrm{H}$ vibrations belonging to the lignin phenols and to the hydroxyl bands of the cellulose and hemicellulose (3400-3420 $\left.\mathrm{cm}^{-1}\right)$ do not present significant 
changes in each of the analysis times, which could indicate that there was no degradation. On the other hand, the bands belonging to the vibrations of the $\mathrm{COOH}$; stretching of the $\mathrm{O}$ $\mathrm{H}$ of carboxylic acid (3000-2201 $\left.\mathrm{cm}^{-1}\right)$ showed changes that indicate the degradation of these bonds in the presence of
$\mathrm{Ca}(\mathrm{OH})_{2}$, being more noticeable in the samples covered with flaxseed oil. It can then be concluded that paraffin adequately protected the fibers from alkaline degradation.
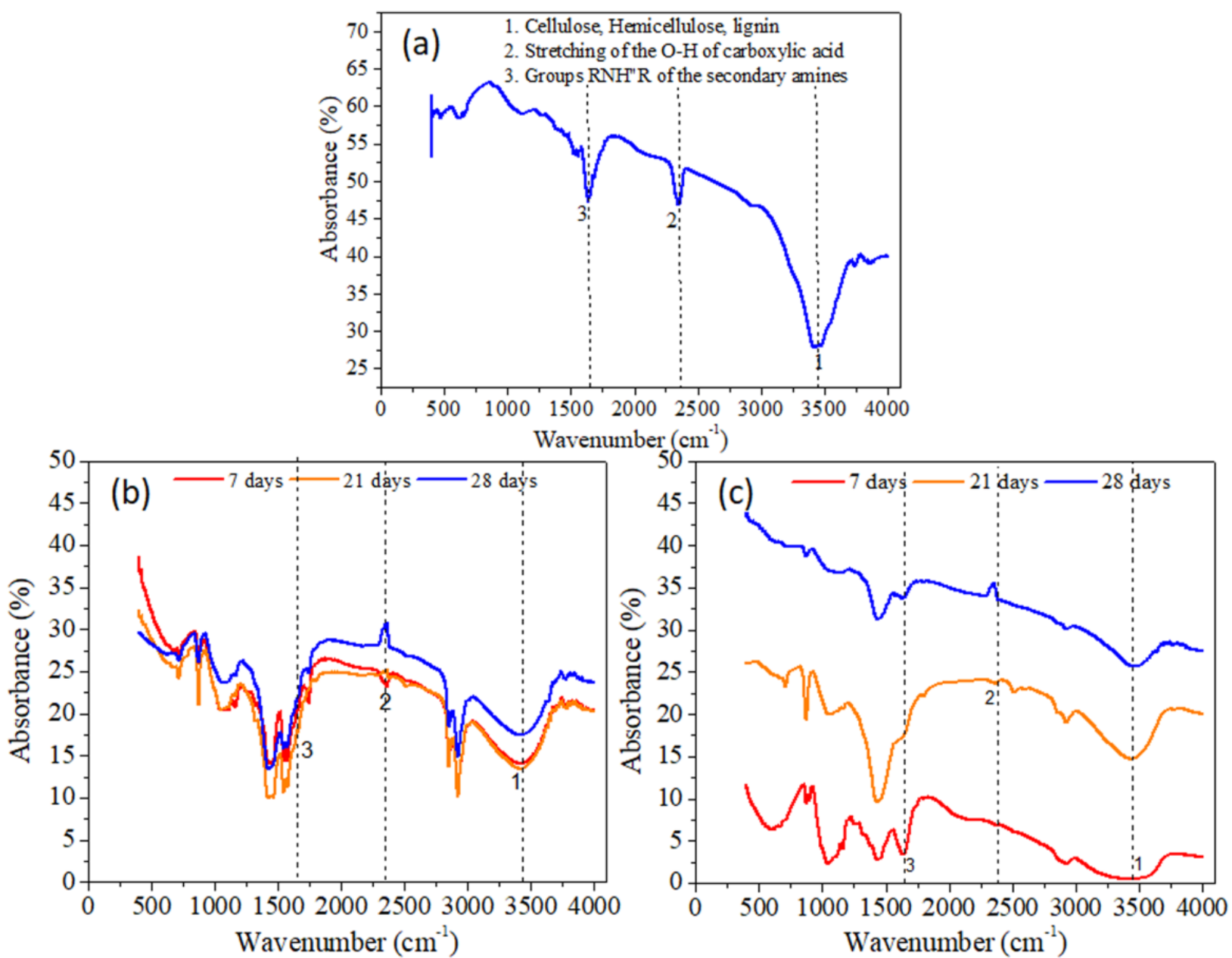

Fig. 4. The FT-IR spectrum of maize fiber a) Uncoated, b) coated with paraffin and c) coated with flaxseed oil submerged for 7,21 and 28 days in $\mathrm{Ca}(\mathrm{OH})_{2}$.

\subsubsection{Thermal Analysis.}

The process of thermal decomposition in the absence of oxygen of a lignocellulosic substance generates tars, gases, and coal. It is known that hemicellulose starts the thermal decomposition process at around $180{ }^{\circ} \mathrm{C}$ and is largely responsible for the generation of gases. The central region of the fibers is responsible for the high amount of water absorbed, due to the large number of permeable pores it has. The cellulose begins its degradation at $240{ }^{\circ} \mathrm{C}$ and the lignin at $280^{\circ} \mathrm{C}$ and depending on the degree of polymerization of the components of the fibers, there will be a greater or lesser degree of solubility in the aqueous or alkaline medium, which can cause, by decomposition, the loss of the mechanical resistance of the fiber when used as reinforcement. Therefore, it can be concluded that the degradation process of the fibers begins in its superficie since the alkali of the cement attacks the cells from the most external fibers to the most internal ones, in which its effect will be notably detrimental in the behavior of the fibers [34].

Figure 5 shows the thermogravimetric analysis (TGA) of corn fiber, which shows 3 important mass loss stages. The first stage is presented from room temperature $\left(\mathrm{T}_{\text {initial }}=25^{\circ} \mathrm{C}\right)$ to $157.85{ }^{\circ} \mathrm{C}$ and corresponds to the loss of humidity (Hm) present in the sample muestra $[35,36]$ which was $7.48 \%$. The second stage is between $157.85{ }^{\circ} \mathrm{C}$ and $350{ }^{\circ} \mathrm{C}$, which corresponds to the simultaneous degradation of cellulose, hemicellulose, and part of lignin [37], and represents a loss of the total weight of the sample of $62.45 \%$. The volatile products of decomposition at this stage would be mainly bound water, $\mathrm{CO}$ and $\mathrm{CO}_{2}$ [35].

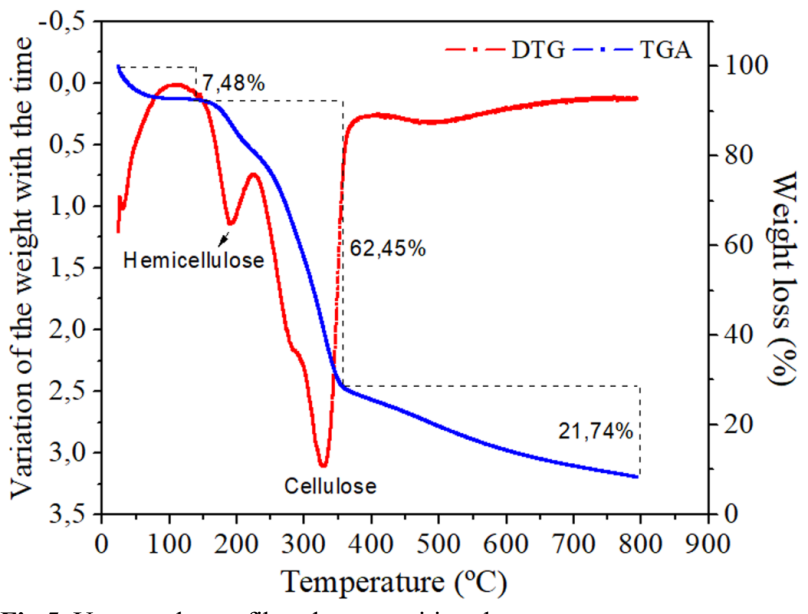

Fig 5. Untreated corn fiber decomposition thermogram. 
The last stage, which is between $350^{\circ} \mathrm{C}$ and $770^{\circ} \mathrm{C}$, represents $21.74 \%$ of the weight loss of the sample and refers to the decomposition of the cellulose and the rest of the lignin in the corn fiber [38]. Several authors state that some polysaccharides, lignin, and certain inorganic substances may be responsible for the continuity of the degrading processes of the fibers, which may occur even at temperatures above $550^{\circ} \mathrm{C}$ [39]. As for the mass variation of untreated corn fiber with respect to time, it was analyzed by Derived Thermogravimetry (DTG), the results showed the presence of 2 peaks of maximum speed in the loss of mass (see Figure 5), the first one was presented at around $185.78{ }^{\circ} \mathrm{C}$ and was attributed to the decomposition of hemicellulose and the second one was presented at $327^{\circ} \mathrm{C}$ and was attributed to the decomposition of cellulose. The second peak corresponds to the greatest weight loss on the TGA curve and indicates the temperature at which the fiber degraded most rapidly [22, 40]. When comparing the thermogravimetric behavior of uncoated corn fiber coated with flaxseed oil and paraffin (see Figure 6), it was observed that the coated fibers have 3 important weight loss regions and a fourth less visible region (see Figure 6a). The first region refers to the loss of moisture present in the sample, the fiber coated with flaxseed oil presented a loss of $7.42 \%$ and the fiber coated with paraffin of $7.18 \%$, the losses occurred in the temperature range of $20^{\circ} \mathrm{C}$ to $188^{\circ} \mathrm{C}$.
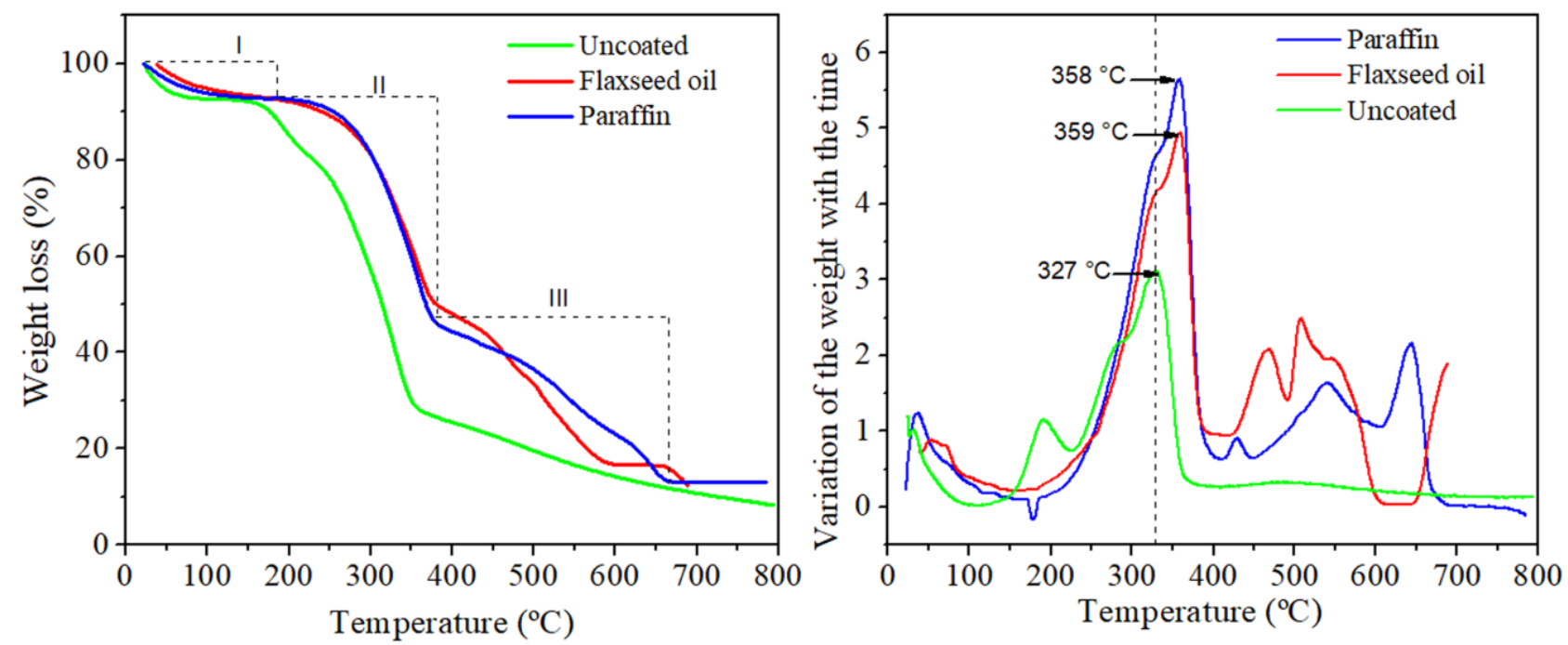

Fig 6. a) TGA curve and b) DTG curve of corn fibers coated with paraffin and flaxseed oil

The second region occurs between $188^{\circ} \mathrm{C}$ and $373.10^{\circ} \mathrm{C}$ and corresponds to the simultaneous degradation of the cellulose, hemicellulose, and part of the lignin and the extracts present in the sample, i.e., carbohydrates, sugars, starches and many others not eliminated in the fiber extraction process. Weight loss for flaxseed oil -coated fiber was $41.42 \%$, while for paraffin-coated fiber it was $46.24 \%$. As for the third region, it occurs between $373^{\circ} \mathrm{C}$ and $663.48^{\circ} \mathrm{C}$ and corresponds to the decomposition of hemicellulose. Weight loss for flaxseed oil -coated fiber was $33.31 \%$ and for paraffin-coated fiber was $33.85 \%$. As cellulose is a biopolymer with a strong and orderly structure, it decomposes in a higher temperature range $\left(360^{\circ} \mathrm{C}-660^{\circ} \mathrm{C}\right)$. The least visible region $\left(\mathrm{T}>660^{\circ} \mathrm{C}\right)$ would represent the decomposition of the final residue and according to previous research [39, 41], would be attributed to the degradation of lignin, since its decomposition occurs between $100^{\circ} \mathrm{C}$ and $900^{\circ} \mathrm{C}$.

When comparing the variation of the mass of uncoated corn fiber coated with flaxseed oil and paraffin with respect to time (See Figure 6b), the results show an improvement in its thermal stability when coated, since it produces an inhibition of the peak of hemicellulose decomposition, which occurred around $185.78^{\circ} \mathrm{C}$ and a shift in the peak of cellulose degradation to higher temperature values, from $327^{\circ} \mathrm{C}$ to 358 ${ }^{\circ} \mathrm{C}$ and $359{ }^{\circ} \mathrm{C}$ for flaxseed oil and paraffin -coated fiber, respectively [35]. The increase in temperature of thermal decomposition may be related to the partial removal of hemicellulose and lignin and to the higher crystallinity of cellulose [42]. The peaks observed at temperatures above 400 ${ }^{\circ} \mathrm{C}$ were attributed to the degradation of the protective agents since in this temperature range the uncoated fiber does not present a significant variation in its mass.

\subsection{Results of Mechanical Tests}

\subsubsection{Compressive Strength}

The mechanical properties of concrete reinforced with natural fibers can be affected by several factors, according to Aziz et al (1981) the most significant are: the type of fiber, the length and the percentage by weight of the fiber used. The optimum fiber length and volume content depend on the type of fiber used [42] and according to the conditions at the interface, the content of the reinforcement determines the degree of effect on the mechanical properties of the compound [43].

Figure 7 summarizes the results of the compression test of fiber-reinforced mortars sealed with paraffin and flaxseed oil. Figure 7(a) shows that the compressive strength of paraffincoated corn-fiber reinforced mortars at 28 days of curing was superior to that of flaxseed oil coated corn-fiber reinforced mortars. This behavior shows that paraffin more adequately protected the fiber from the chemical and physicochemical point of view, modifying the fiber/mortar interface producing a lower water absorption capacity. The best results were obtained in mortars reinforced with $0.5 \%$ by weight of corn fibers with $1 \mathrm{~cm}(8.3 \mathrm{MPa})$ and $2 \mathrm{~cm}(8.1 \mathrm{MPa})$ in length and coated with paraffin. [44] reinforced concrete with bagasse fibers treated in $\mathrm{Ca}(\mathrm{OH})_{2}$ to $5 \%$ for 24 hours; they also found that the compressive strength increased with the addition of $0.5 \%$ fibers [44].

The length of the fiber affects how it can be aligned and arranged as reinforcement. Short fibers are difficult to align, 
which explains why they are usually included at random. The maximum fiber load and the maximum strength of the reinforced mortar are reached when the fibers are aligned parallel to a unitary axial load. In this case, the greatest resistance was obtained with the short fibers since they present an isotropic behavior before the mechanical efforts.
[45] studied the mechanical behavior of sisal fiber-reinforced mortars of different lengths, found that these fibers did not improve compressive strength; however, long-length fibers had a more detrimental effect compared to shorter ones. This can be attributed to a decrease in mortar density, associated with an increase in porosity [45].
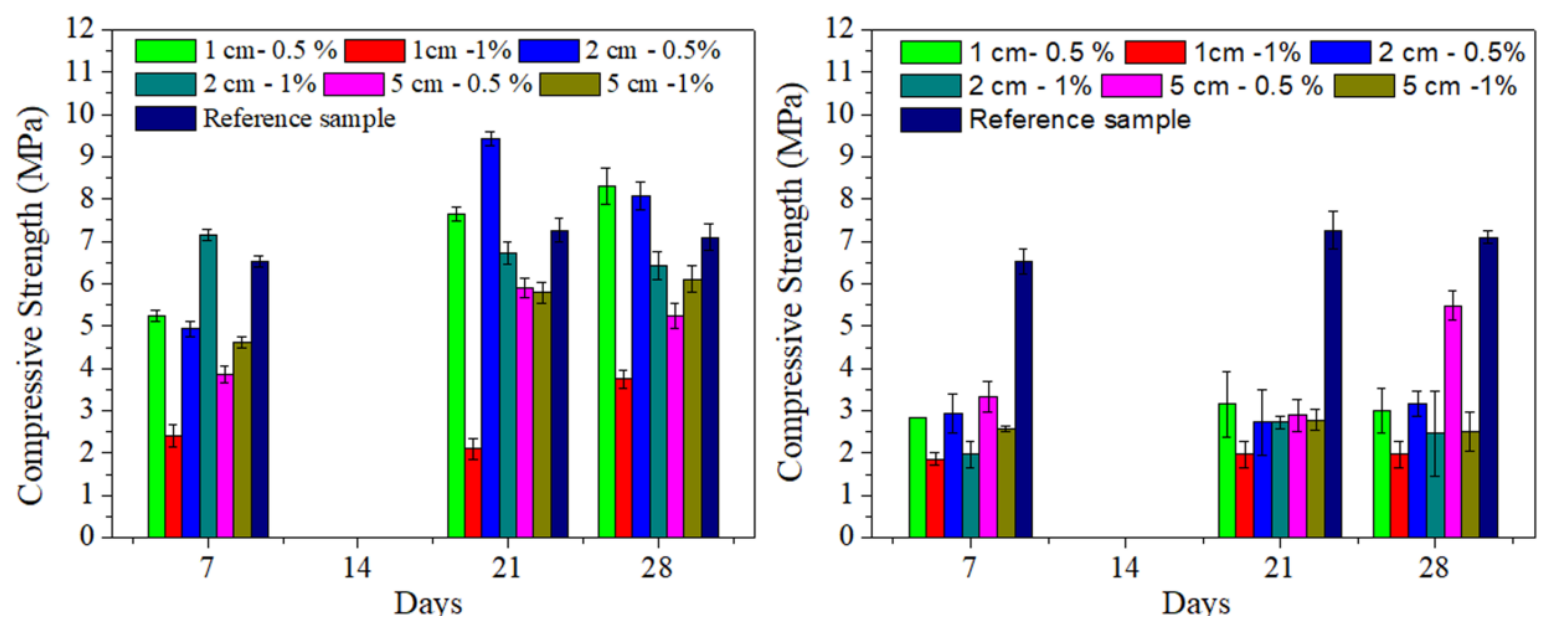

Fig. 7. Compression test results for fiber-reinforced mortars impregnated with (a) paraffin and (b) flaxseed oil.

Aziz et al [46] stated that a high amount of fiber makes mixing difficult and tends to clump together, generating inadequate adhesion which decreases its strength and can also lead to a reduction in the workability of fresh concrete, which can result in increased porosity [47]. In addition to that, the fiber content has a significant effect on specific gravity, water absorption, and moisture movements and it is observed that with an increase in the percentage of fiber the specific gravity is reduced and water absorption and moisture movements increase [48].

Figure 7(b) shows that for all the cases studied, the compressive strength of flaxseed oil-coated corn-fiber reinforced mortars is lower than that obtained with the control mortar $(7.1 \mathrm{MPa})$. This behavior can be attributed to the low surface protection obtained in the fiber by flaxseed oil, which allowed its further degradation due to the alkaline elements contained in the cement, this could affect the adhesion of the

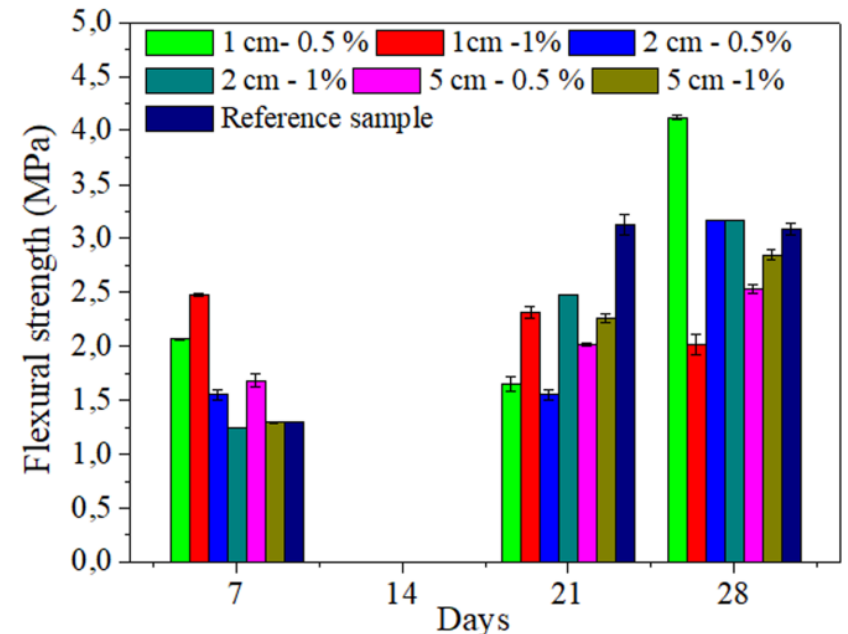

fibers to the cemented matrix, generating spacing in the fiber/matrix interface. These spaces reduce the compactness of the cement and thus the compressive strength of the fiberreinforced mortar [6]. Another possible cause of the low compressive strength of flaxseed oil-coated fiber-reinforced specimens compared to non-reinforced specimens [19] was the phenomenon of bleeding, which occurs in concrete and mortars with a high water/cement ratio. The results show that flaxseed oil did not adequately protect the fiber (see Figure 3 ), which allowed for marked deterioration due to increased water absorption.

\subsubsection{Bending Strength}

Figure 8 summarizes the results of the bending test of paraffin- and flaxseed oil-waterproofed fiber-reinforced mortars.

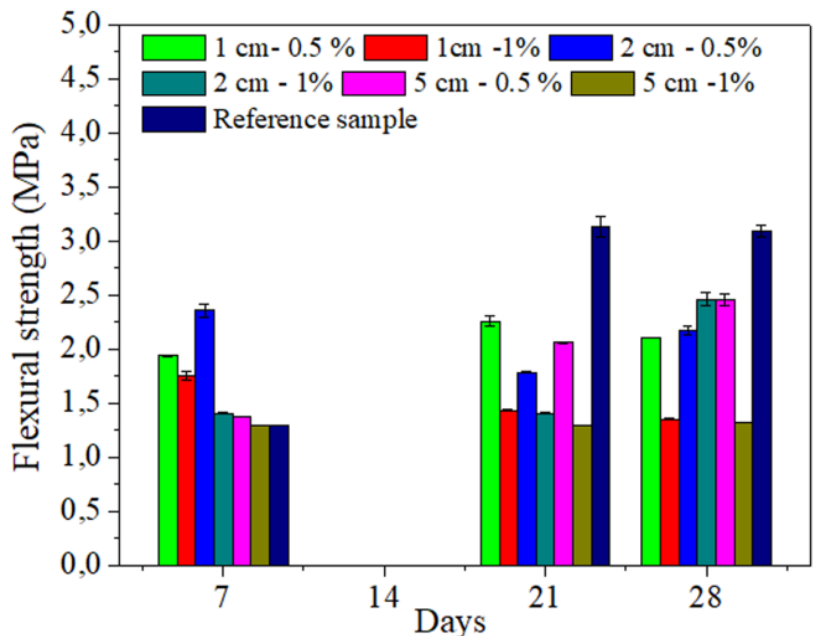

Fig. 8. Test results for flexural strength of fiber-reinforced mortars impregnated with (a) paraffin and (b) flaxseed oil.

Higher flexural strength is noted for mortars with paraffin-impregnated fibers (see Figure 8a) compared to those with flaxseed oil (see Figure $8 \mathrm{~b}$ ). This is due to the fact that the paraffin-treated fibers showed good chemical resistance and lower water absorption capacity, while in the fibers treated with flaxseed oil, the fibers showed a great degradation in the presence of the alkaline elements contained in the cement, which caused the adhesion between the fiber 
and the matrix to decrease, making the fiber fragile and therefore decreasing its resistance to bending, as reported by Juarez et al (2004) [19].

Figure 8 (a) shows that the mortars that had the best results 28 days after curing were those that were reinforced with paraffin-coated corn fiber with a length of $1 \mathrm{~cm}$ and $0.5 \%$ by weight with a value of $4.12 \mathrm{MPa}$, higher than the value of the control mortar $(3.09 \mathrm{MPa})$. The length of the fiber drastically influences the bending strength, long and continuous fibers can be aligned in a specific direction. However, unidirectional orientations cause poor properties if the load is perpendicular to these fibers [49]. It is for this reason that mortars reinforced with $1 \mathrm{~cm}$ and $0.5 \%$ by weight fibers, having short fibers, are aligned randomly and show an isotropic behavior to mechanical stresses and thus an improvement in the resistance to bending. Juárez C. et al (2004) also found that reinforcing concrete with lechuguilla fibers with a percentage by volume of $0.5 \%$ increased flexural strength and that this strength decreased as the percentage by volume of fiber increased [19].

The improvement in flexural strength is due to the fact that fiber reinforcements improve the tenacity of the matrix in several ways, as cracks that may appear in the matrix are transmitted to the fibers, absorbing energy and blocking the spread of cracks. A poor bond between the fiber and the matrix can cause the fiber to begin to separate from the matrix, increasing the possibility of fractures [41], in which case the crack is forced to propagate around the fiber in order to continue the fracture process. Both processes consume energy and therefore increase fracture toughness. Finally, when the crack in the matrix begins, the unfractured fibers can still form a bridge over the crack, providing compressive stress that prevents the crack from opening [48].

\section{Conclusions}

Natural fibers such as corn fiber are a good alternative as reinforcement for the production of structural type mortar, according to the results obtained showed an increase in the compressive and flexural strength of $16.92 \%$ and $38.51 \%$ respectively, compared with unreinforced mortar.

Thermogravimetric analysis was very useful to visualize the existence of three clear regions in the thermal degradation of the fibers studied. The first region reveals moisture loss, the second region is associated with the extractives present in the sample and the third region indicates thermal degradation of hemicellulose and cellulose. Paraffin and flaxseed were found slightly to increase the thermal stability of the fibers.

Paraffin treatment improves the chemical resistance of the fiber, reducing the water absorption capacity and providing good protection against the alkaline medium of the cement. The fibers added in small percentages $(0.5 \%$ by weight) improve the resistance to compression and flexion since they do not hinder the mixing.

The short fibers $(1 \mathrm{~cm})$ are aligned at random, presenting an isotropic behavior to mechanical stresses, improving the compressive and flexural strength compared to the control mortar.

This is an Open Access article distributed under the terms of the Creative Commons Attribution License

\section{References}

[1] H. Danso, Procedia Engineering, 200 (2017) 1-9.

[2] G. Lewis, M. Premalal, Magazine of Concrete Research, 31 (1979).

[3] A. Abdullah, S.B. Jamaludin, M.I. Anwar, M.M. Noor, K. Hussin, Physics Procedia, 22 (2011).

[4] D. Sanchez de Guzmán, Tecnología del concreto y del mortero, 2001.

[5] N. Perumalsamy, SPS. Balaguru, Fiber-reinforced cement composites, McGraw Hill, New York, 1992.

[6]J. Osorio, F. Varón, J. Herrera, DYNA, 74 (2007).

[7] A. Bentur, S. Mindess, Fibre Reinforced Cementitious Composites, Taylor and Francis, 2007.

[8] V. Agopyan, H. Savastano, V.M. John, M.A. Cincotto, Cement and Concrete Composites, 27 (2005).

[9] C. Reyes, Departamento de Construcciones Arquitectónicas 1, Universidad Politécnica de Catalunya 2009, pp. 430.

[10] M. Prado-Martínez, J. Anzaldo-Hernández, B. Becerra-Aguilar, H. Palacios-Juárez, J.d.J. Vargas-Radillo, M. Rentería-Urquiza, Madera y bosques, 18 (2012).

[11] K.D. González Velandia, D. Daza Rey, P. A Caballero Amado, Martínez González, C, Revista Luna Azul 43 (2016).

[12] S.R.D. Petroudy, Physical and mechanical properties of natural fibers, in: F.F. Mizi Fan (Ed.) Advanced High Strength Natural Fibre Composites in Construction, Elsevier, 2017, pp. 569.

[13] E.J.d. Silva, M.L. Marques, F.G. Velasco, C. Fornari Junior, F.M. Luzardo, M.M. Tashima, Sustainable Materials and Technologies, 12 (2017).

[14] A.S. Singha, V.K. Thakur, International Journal of Polymer Analysis and Characterization, 14 (2009).

[15] Internacional I. Norma Técnica Colombiana NTC 673 "Concretos. ensayo de resistencia a la compresión de especimenes cilíndricos de concreto" (2010)

[16] ASTM C470-02 "Standard Specification for Molds for Forming Concrete Test Cylinders Vertically". (2002)
[17] Internacional I. Concretos. métodos de ensayo para determinar la evaluación en el laboratorio y en obra, de morteros para unidades de mampostería simple y reforzada. (2003).

[18] Instituto Nacional de Vías. Resistencia a la flexión de morteros de cemento hidraúlico I.N.V.E - 324- 07

[19] C.A Juarez, Facultad de Ingeniería Mecánica y Eléctrica, Universidad Autonoma de Nuevo León, (2002).

[20] C.D. Johnston, Taylor \& Francis, 2010, pp. 261.

[21] L.R. Sepúlveda, Ingeniería Industrial, Universidad Nacional de Colombia, 2014.

[22] C. Juárez, P. Rodríguez, Ingenierías, 7 (2002).

[23] J.d.A. Melo Filho, F.d.A. Silva, R.D. Toledo Filho, Cement and Concrete Composites, 40 (2013).

[24] V.A. Alvarez, A. Vázquez, Composites Part A: Applied Science and Manufacturing, 37 (2006).

[25] J. Wei, C. Meyer, Cement and Concrete Research, 73 (2015).

[26] K. Bilba, M.-A. Arsene, A. Ouensanga, Bioresource Technology, 98 (2007).

[27] P. Romero, S. Marfisi, P Oliveros, B. Rojas de Gáscue, G. Peña, Revista Iberoamericana de Polímeros, 15 (2015).

[28] H. Contreras, H. Trujillo, G. Arias, J. Pérez, E. Delgado, e-Gnosis, 8 (2010).

[29] F.R. Callejas.

[30] Z. Luo, P. Li, D. Cai, Q. Chen, P. Qin, T. Tan, H. Cao, Industrial Crops and Products, 95 (2017).

[31] http://depa.fquim.unam.mx/amyd/archivero/Tabla_de_IR_20785.pd f.

[32] F.C. Navarrete, Departament d'Enginyeria Química, Universitat Politècnica de Catalunya, 2002.

[33] N. Mendoza, Facultad de ciencias químicas, Universidad Complutense de Madrid, 2013.

[34] B. Paricaguán, C. Albano, J. Palacios, R. Torres, N. Camacho, J. Infante, M. Alvarado, Revista INGENIERÍA UC, 20 (2013). 
Mónica Monsalve, Oscar Higuera, Pedro Estrada, Marlyn Orozco and Cristian Pedraza/

Journal of Engineering Science and Technology Review 12 (4) (2019) 69 - 77

[35] P. Pineda-Gómez , D.F. Coral, D. Ramos-Rivera y A. RosalesRivera, . Ingeniería y Ciencia, 7 (2011).

[36] B. Paricaguán, C. Albano, J. Palacios, R. Torres, NelsonCamacho, Revista INGENIERIA UC, 20 (2013)

[37] S.R. Ferreira, F.d.A. Silva, P.R.L. Lima, R.D. Toledo Filho, Construction and Building Materials, 101 (2015)

[38] J. Wei, C. Meyer, Corrosion Science, 88 (2014).

[39] A. Jimenez, S. Betancourt, P. Gañán, L. Cruz, Degradación térmica de fibras naturales procedentes de la calceta de plátano. (Estudio cinético), 2009.

[40] J. Wei, C. Meyer, Cement and Concrete Research, 81 (2016).

[41] G. Quintero, Facultad de Ingeniería y Administración, Universidad Nacional de Colombia, sede Palmira, 2003, pp. 156

[42] M. Li, S. Zhou, X. Guo, Construction and Building Materials, 150 (2017).
[43] M. Garzón, V. Barros, H. Ramírez, Facultad de Ingeniería, Ciencias Físicas y Matemática, Universidad Central de Ecuador, Ecuador, 2012.

[44] J. Osorio, F. Varón, J. Herrera, DYNA, 74 (2007).

[45] F.D. R. Fujiyama, M. V. Pereira., THEORETICAL \& APPLIED MECHANICS LETTERS 4(2014).

[46] M.A. Aziz, P. Paramasivam, S.L. Lee, International Journal of Cement Composites and Lightweight Concrete, 3 (1981).

[47] L. Yan, B. Kasal, L. Huang, Composites Part B: Engineering, 92 (2016).

[48] S. Quintero, L. Gonzalez, Revista INGENIERÍA \& DESARROLLO, 20 (2006).

[49] L. Gonzalez, Universidad Nacional de Colombia, 2013, pp. 32. 